\title{
Analysis of Role of Fisherman Institution in Overcoming Poverty Vulnerability of Fisherman's Household in Tanggamus Regency of Lampung Province, Indonesia
}

\author{
Maya Riantini ${ }^{*}$, Muhammad Yazid², Laila Husin ${ }^{3}$, Dessy Adriany ${ }^{4}$ \\ ${ }^{1}$ Study Program of Agricultural Agribusiness, Faculty of Agriculture, Sriwijaya University, Palembang, Indonesia \\ ${ }^{2,3}$ The lecturer of Agricultural Agribusiness, Faculty of Agriculture, Sriwijaya University, Indralaya, South Sumatera, Indonesia
}

\begin{abstract}
Institutional role for coastal communities is very important to achieve a more prosperous society. This can further lead to the need for a supportive institutional role so that it can reduce the level of vulnerability of poverty in fisherman's households. This research aims to analyze the role of fisherman's institutions in overcoming the vulnerability of poverty in fisherman's households. Data used in this research are primary data and secondary data. From the results of the data, the role of fisherman's institution is conducted by scoring the role of fisherman's institution to the institution in Tanggamus Regency. From the result of the data, it can be seen that the role of institutions that have enough role to overcome the vulnerability of the modern fisherman's household are (1) Fish Market (Tempat Pelelangan Ikan, TPI) 2) Business Group (Kelompok Usah Bersama, KUBE), while the role of institutions that play a role in overcoming the vulnerability of traditional fisherman's households are (1) Fish Resources Monitoring Community Group (Kelompok Masyarakat Pengawas Sumberdaya Ikan, POKMASWAS), (2) Fishermen Insurance and (3) Association of Fishermen in Indonesia (HNSI)
\end{abstract}

Keywords: role, institutional, vulnerability, poverty, household

\section{Introduction}

Development implemented in Indonesia aims to achieve the welfare of the society by seeking economic growth. One of the efforts made to make it happen is through agricultural development. Agricultural development is an effort to utilize sustainable natural resources, human resources, capital, and science and technology to produce agricultural production and industrial primary raw materials (State Policy Outline, 1993).

The fishery sector plays an important role in the Indonesian economy. The importance of the role of the fisheries sector is intended by several things, they are: (1) fishery resources, decreasing and abundant water in which its utilization is not optimal yet, (2) the contribution of the fishery sector to the Gross Domestic Product (GDP) is still relatively small, but tends to increase, (3) the increased demand for fish from year to year, but it is not counterbalanced with the supply, (4) society is more selective in fulfilling nutritional requirement coming from fishery sector, and (5) and the highly growing populations that have the potential to grow the fishery production centers (Kusumaatmadja, 2000).

A number of problems faced by fishermen require an institutional role for fishermen to get out of the problems they face. For example, institutions that can tackle capital for fishermen to catch fish. In addition, institution that oversees the traffic activity of tanker which is very disturbing fishermen to go to sea, the institution that oversees environmental pollution around the sea. With the institutional role for the fishermen, it is expected to change traditional fishermen become more modern fishermen. Traditional fishermen are people who are directly active in fishing on the sea by small boat or size of 1 Gross Ton and fishing or shrimp fishing gear. Meanwhile, modern fishermen are fishermen who do fishing in the sea with large ships with the size of 5 to $10 \mathrm{GT}$ (Gross Ton) and fishing gear nets and fishing and shrimp fishing gear rods.

An institution is a set of rules within a community or organization that facilitate coordination among its members to assist them for the sake of that everyone can cooperate or relate to each other to achieve their desired common goals, as suggested by Ruttan and Hayami (1984).

Institutions that are grown and shaped by local communities have in fact contributed to the development of villages in their areas, including: Providing information on community issues and needs, accelerating village development targets, assisting the government in socializing village development, being the government's partner in the improvement of social welfare of the community. The role of local institutions in coastal community in Jember Regency can improve their economy $(53.33 \%)$ by providing venture capitals in the forms of saving and loan activities in the forms of cooperative organizations. In addition, $33.33 \%$ (percent) of local institutions play a role in increasing the capacity of human resources as business actors and providers of agricultural production and capture fisheries by providing free advisories to help farmers and fishermen get out of their problems (Hadi, 2014).

Vulnerability develops on the coast due to several factors, namely: (1) coastal resources are often open access, at least,

Volume 6 Issue 12, December 2017 


\section{International Journal of Science and Research (IJSR) \\ ISSN (Online): 2319-7064 \\ Index Copernicus Value (2016): 79.57 | Impact Factor (2015): 6.391}

de facto, (2) being the most depressed areas due to various development activities and development impacts, and (3) areas that are underestimated when viewed from the availability of public facilities and infrastructure. In addition, the factors that influence the continued development of coastal poverty are population density, low population quality, and lack of access to capital, technology and market resources (Directorate General for Coasts and Small Islands, 2000).

Mussawir's research results (2009) showed that the poverty of traditional fishermen in Padang Panjang Village was caused by 3 (three) factors are: (1) quality of human resources, (2) economic factor, and (3) institutional factor.

\section{Material and Method}

This research was conducted in Tanggamus Regency, Lampung Province of Indonesia. Determination of this location was carried out intentionally (purposive), considering that in the region of Tanggamus Regency, there are many traditional fishermen.

This research is descriptive verificative. Descriptive verificative research is a research which aims to test the effects of two or more variables. The data are collected from the fisherman's households when the research was conducted. In this research, the data are also chopped on any factor that influences the vulnerability of fisherman's household.

Sampling technique was conducted by using a simple random method. Methods of data collection techniques used are observation, interview, documentation, and questionnaire. The sample size of 200 respondents for each research location is determined proportionally with the Slovin formula in which alfha $(\alpha)$ of $1 \%$ or $0.01 \%$ (Sugiyono, 2012).

Analysis of the role of social institutions and participation of fisherman's households in overcoming vulnerability using qualitative data analysis methods. Institutions studied in this research include Fish Market (TPI), Joint Business Groups (KUBE), Community Monitoring Groups (POKWASMAS), Fishermen Insurance, and Association of Fishermen in Indonesia (HNSI). Evaluation of the role of fishermen's institutions was carried out by scoring the role of each fisherman to the existing institutions in Tanggamus Regency.

\section{Result and Discussion}

To examine the role of fishermen's institution to institutions in Tanggamus Regency, there are several stages, ie the first stage is Focus Group Discussion (FGD) and Participatory Rural Appraisal (PRA) activities. FGD activity was carried out by the reviewers in order to obtain a more accurate picture of the data and to arrange an appropriate activity program plan to address existing problems based on previously obtained data. In FGD, the researcher plays a double role, as a discussion facilitator and observer of the discussion in preparing the program desired by fishermen in Tanggamus Regency. Participants in FGD are fishermen and Department of Marine and Fishery.

Participatory Rural Appraisal (PRA) is an assessment of institutional roles in Tanggamus Regency to make more independent fishermen in overcoming the vulnerability of fishermen's poverty. In this case, the reviewer used the method referred to is a joint activity between researchers and fishermen in mapping a region to identify the problems, potential, and fishermen's needs in an effort to overcome the vulnerability of fishermen's households in Tanggamus Regency. Thus, it can make program planning well.

The institutional roles studied in this research looked at several institutional roles in Tanggamus Regency: (1) Fish Market (Tempat Pelelangan Ikan,TPI), (2) Joint Business Group Institution (Kelompok Usaha Bersama,KUBE), (3) Community Monitoring Group Institution (Kelompok Masyarakat pengawas Ikan, POKWASMAS), (4) Fishermen Insurance Institution, and (5) Association of Fishermen in Indonesia (HNSI). Institutional role in overcoming vulnerability of fishermen's households in Kabupaten Tanggamus Can be seen in Table 1.

The expectation of an active institutional role of all fishermen in Tanggamus Regency is able to make fishermen more independent and towards more prosperous fishermen. Fishermen in vulnerable conditions are feared that they will fall into poverty if there are no local government roles. The role of government is needed in establishing the institutions that are in favor of the fishermen. Institutions are highly expected by fishermen that they can help fishermen go out of vulnerable conditions so that they can be far from falling into poverty. In addition, the role of the institution can be as a distributor of fishermen's aspirations to the local government. The name and role of the institutions in Tanggamus Regency can be seen in Table 1 .

Table 11: Role of Institutions in Overcoming Vulnerability in Tanggamus Regency, 2017.

\begin{tabular}{|c|c|c|c|}
\hline No & Institution's Name & Detail & Role \\
\hline 1 & $\begin{array}{c}\text { Fish Market (Tempat Pelangan Ikan, } \\
\text { TPI) }\end{array}$ & $\begin{array}{c}\text { Fishermen, Joint } \\
\text { Business Group }\end{array}$ & $\begin{array}{c}\text { 1. As a supporting infrastructure of fishermen's activities to conduct fish } \\
\text { catching activity } \\
\text { 2. As a place of processing of fish catched and marketing for fishermen }\end{array}$ \\
\hline 2 & $\begin{array}{c}\text { Joint Business Group (Kelompok } \\
\text { Usaha Bersama, KUBE) }\end{array}$ & Fishermen & 1. Participate in managing business groups in Tanggamus Regency \\
\hline 3 & $\begin{array}{c}\text { Fish Resources Monitoring } \\
\text { Community Group (Kelompok } \\
\text { Masyarakat Pengawas Sumberdaya } \\
\text { Ikan, POKMASWAS) }\end{array}$ & $\begin{array}{c}\text { Village Chief, } \\
\text { Customary Chief, } \\
\text { Fishermen, Local } \\
\text { Community }\end{array}$ & Supervision of fish resources at the field level. \\
\hline 4 & Fishermen Insurance & Fishermen & Serve as a protection warranty against the risks of fishermen, fish farmers \\
\hline
\end{tabular}




\section{International Journal of Science and Research (IJSR) \\ ISSN (Online): 2319-7064}

Index Copernicus Value (2016): 79.57 | Impact Factor (2015): 6.391

\begin{tabular}{|c|c|c|c|}
\hline & & & and salt farmers \\
\hline 5 & $\begin{array}{c}\text { Association of Fishermen in } \\
\text { Indonesia (Himpunan Nelayan } \\
\text { Seluruh Indonesia, HNSI) }\end{array}$ & Fishermen & $\begin{array}{c}\text { as a mediator between fishermen who are members with interested parties, } \\
\text { especially the Department of Marines and Fisheries in Tanggamus Regency }\end{array}$ \\
\hline
\end{tabular}

To find out how big the role of fishermen's institutions in Tanggamus Regency, in this case, the government and fishermen, there will be a scoring approach. Scoring is measured based on respondents' answers on the role of government, the role of modern fishermen, and the role of traditional fishermen to the institutions which exist in Tanggamus Regency. Institutional role is carried out by scoring on each role of institutions followed by fishermen, it can be seen in Table 2 .

Table 2: Scoring of Institutional Role of Modern Fishermen and Traditional Fishermen in Tanggamus Regency, 2017.

\begin{tabular}{|c|c|c|c|c|c|c|c|c|c|c|c|c|c|}
\hline \multirow{3}{*}{ No } & \multirow{3}{*}{ Institution's Name } & \multicolumn{5}{|c|}{$\begin{array}{c}\text { Modern Fishermen } \\
(n=112)\end{array}$} & \multirow[t]{3}{*}{$\begin{array}{c}\text { Average } \\
\text { score }\end{array}$} & \multicolumn{5}{|c|}{$\begin{array}{c}\text { Traditional } \\
\text { Fishermen }(n=88)\end{array}$} & \multirow[t]{3}{*}{$\begin{array}{c}\text { Average } \\
\text { score }\end{array}$} \\
\hline & & VI & I & $\mathrm{IE}$ & $\mathrm{LI}$ & $\mathrm{NI}$ & & VI & $\mathrm{I}$ & IE & LI & $\mathrm{NI}$ & \\
\hline & & 5 & 4 & 3 & 2 & 1 & & 5 & 4 & 3 & 2 & 1 & \\
\hline 1 & Fish Market (Tempat Pelangan Ikan, TPI) & 0 & 8 & 32 & 38 & 33 & 3,8 & 6 & 49 & 31 & 2 & 0 & 2,3 \\
\hline 2 & $\begin{array}{c}\text { Joint Business Group (Kelompok Usaha Bersama, } \\
\text { KUBE) }\end{array}$ & 0 & 13 & 24 & 29 & 45 & 3,9 & 2 & 54 & 32 & 0 & 0 & 2,3 \\
\hline 3 & $\begin{array}{c}\text { Fish Resources Monitoring Community Group } \\
\text { (Kelompok Masyarakat Pengawas Sumberdaya } \\
\text { Ikan, POKMASWAS) }\end{array}$ & 0 & 63 & 38 & 8 & 2 & 2,5 & 0 & 0 & 39 & 39 & 10 & 3,7 \\
\hline 4 & Fishermen Insurance & 0 & 18 & 81 & 12 & 0 & 2,9 & 0 & 7 & 60 & 10 & 11 & 3,3 \\
\hline 5 & $\begin{array}{c}\text { Association of Fishermen in Indonesia } \\
\text { (Himpunan Nelayan Seluruh Indonesia, HNSI) }\end{array}$ & 0 & 41 & 47 & 22 & 1 & 2,8 & 0 & 21 & 49 & 18 & 0 & 3,0 \\
\hline
\end{tabular}

Note: Very Important (VI), Important (I), Important Enough (IE), Less Important (LI), Not Important (NI)

The results of the score in above table show that the score of the role of Fish Market (TPI) in overcoming the vulnerability of modern fishermen's household is average on the score 3.86 (rounded to 4) so it is classified into important. This means that most respondents stated that the Fish Market (TPI) plays a role in overcoming the vulnerability of fishermen's households in Tanggamus Regency. The role of Fish Market (TPI) in addressing vulnerability is very important, because the good management of Fish Market (TPI) is a manifestation of the presence of the role of government's institution in realizing the welfare of fishermen.

The role of Fish Market (TPI) in overcoming the vulnerability of traditional fishermen is on average score of 2.3 (rounded to 2) so it is classified into less important. This means that most of traditional fishermen declared the Fish Market (TPI) is less important in overcoming the vulnerability of fishermen's households.

The Institutional role of Joint Business Group (KUBE) in overcoming the vulnerability of modern fishermen's households is average score of 3.9 (rounded to 4), it is classified into important. This means that KUBE plays a role in overcoming the vulnerability of fishermen's households. The existence of KUBE is very helpful to the fishermen in reducing the production cost, this is because the fishermen who join in KUBE receive assistance in form of carts, buckets and others. The labor cost is lighter because the fishermen are grouped in group activities in which the production cost and the fishermen's income will be managed well so that the fishermen's income increases. Meanwhile, the role of Joint Business Group (KUBE) in overcoming the vulnerability of traditional fishermen is average score of 2.3 (rounded to 2) so it is classified into less important. It means that the role of Joint Business Group (KUBE) in traditional fisherman is less important in overcoming vulnerability of traditional fisherman's household. Figure of the role of each institution in overcoming the vulnerability of fishermen to modern fishermen can be seen in the picture below.

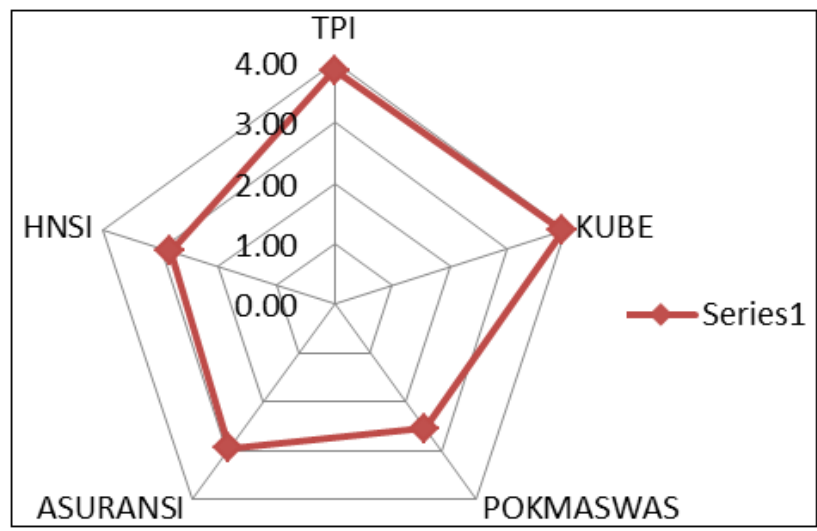

Figure 1: The Role of Institution in Modern Fishermen in Tanggamus Regency

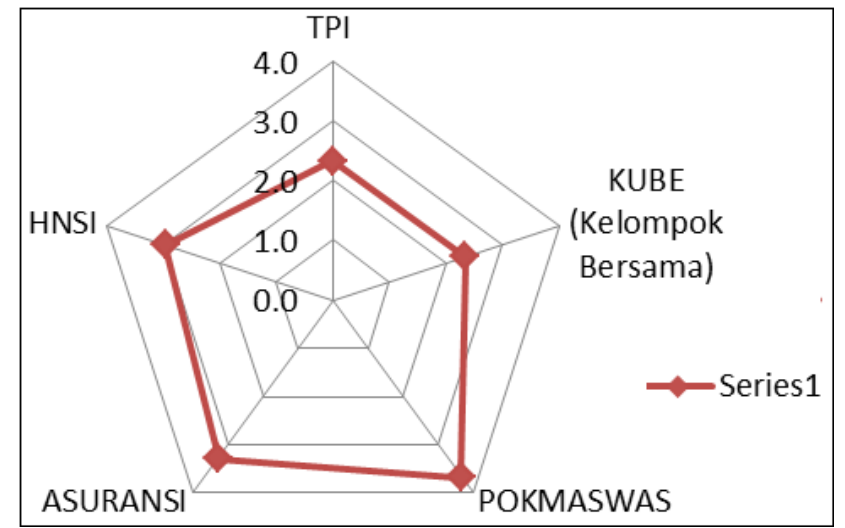

Figure 2: The Role of Institution in Traditional Fishermen in Tanggamus Regency

\section{Volume 6 Issue 12, December 2017 www.ijsr.net}




\section{International Journal of Science and Research (IJSR) \\ ISSN (Online): 2319-7064 \\ Index Copernicus Value (2016): 79.57 | Impact Factor (2015): 6.391}

From the figures above, it shows that the role of Institutions of Fish Market (TPI) and Joint Business Group (KUBE) play a role in overcoming the vulnerability of fisherman's households in modern fishermen. However, in the other hand, the role of institutions of Fish Market (TPI) and Joint Business Group (KUBE) is less important in overcoming the vulnerability of fisherman's households in traditional fishermen. This is because the traditional fishermen are not thinking economically and do not think for the long term, traditional fishermen rely solely on the income from the sea and only to meet the needs on that day only. Thus, traditional fishermen are very vulnerable to be poor.

In addition, traditional fishermen exist a lot in Kelumbayan District where there is no Fish Market (TPI), so the awareness of fishermen to form a Joint Business Group (KUBE) is less, traditional fishermen feel there is still no need to form KUBE and many traditional fishermen do not know the benefits of the existence of KUBE, and this is because the location access to Kelumbayan District is far from the capital city, facilities and infrastructure are inadequate in this district.

The role of Fish Monitoring Community Group Institution (POKMASWAS) in overcoming the vulnerability of modern fisherman's households is average of 2.5 (rounded to 2) so that it is classified into less important. It means POKMASWAS institution has less role to play in overcoming the vulnerability of fisherman's household. On the other hand, the role of POKMASWAS in traditional fishermen in overcoming the vulnerability of fisherman's households is average of 3.7 (rounded to 4) so it is classified into important. This means that POKMASWAS plays a role in overcoming the vulnerability of traditional fisherman's households.

This is because there are many traditional fishermen in Kelumbayan District that is a marine nature reserves area, so the fisherman here is very active to play a role in POKMASWAS institution, fishermen also deeply understand the importance of maintaining the sea. Awareness of fishermen in Kelumbuyan District by forming a group of Marine Nature Reserves (CAL) is also an important key in the economy of traditional fishermen in this area. With the marine nature reserves, in some protected areas, the number of fish increases 2 (two) within 5 years. With the establishment of marine nature reserves formed by POKMASWAS institutions, the fishermen in Kelumbayan Tanggamus District get increased revenue. Not only that, with the marine nature reserves, it is successful to attract visitors of dolphin tours and contribute to the revenue for Tanggamus Regency.

\section{Conclusion and Recommendations}

\subsection{Conclusion}

The role of institutions that are important enough in overcoming the vulnerability of modern fisherman's households are (1) Fish Market (Tempat pelelangan Ikan,TPI) (2) Business Group (Kelompok Usaha Bersama,KUBE), while the role of institutions that play a role in overcoming the vulnerability of traditional fisherman's household are (1) Fish Resources Monitoring Community Group (Kelompok Masyarakat Pengawas Sumberdaya Ikan, POKMASWAS), (2) Fishermen Insurance and (3) Association of Fisherman in Indonesia (HNSI)

\subsection{Suggestion}

The need for institutional role of Fish Market (TPI) and KUBE for fishermen to overcome the vulnerability of fisherman's households, so that the government is expected to provide TPI facilities in each region in Tanggamus Regency in order to increase the fish's selling price.

\section{References}

[1] Directorate General for Coasts and Small Islands. 2000. Preparation of National Guidelines for the Management of Small Islands. Directorate of Marine and Fisheries, Jakarta.

[2] State Policy Guidelines. 1993. Guideline for the Implementation of Tasks of the National Agency for Development Policy and Control. Minister of State Secretariat, Jakarta

[3] Hadi Syamsul, 2014. The role of local institutions in the economic activities of coastal communities in Jember Regency.

[4] Kusumaatmadja, S., 2000. The Renewal of Sustainable Natural Resource Management. Proceedings of the National Dialogue on the Renewal of Natural Resources Management. Gajah Mada University, Yogyakarta.

[5] Mussawir. 2009. Analysis of the Poverty Problem of Tradisional Fishermen in Padang Panjang Village, Susoh District, Southwest Aceh Regency, the Province of Nanggroe Aceh Darussalam. Master Thesis. Graduate School, University of North Sumatra, Medan.

[6] Sugiyono. 2012. Methods of Qualitative Quantitative Research and R\&D. Bandung: Alfabeta

[7] Ruttan dan Hayami. 1984. Toward a theory of induced institutional innovation, Journal of Development Studies. 